\title{
Macumbarias travestis em Castiel Vitorino Brasileiro OU A IMPLOSÁO DO TEATRO DA REPRESENTAÇÃO: CORPO, GÊNERO, NEGRITUDE
}

\author{
Marco Antônio Vieira ${ }^{1}$
}

Resumo: Interessa ao pesquisador como o corpo poético negro e travesti da artista Castiel Vitorino Brasileiro se contrapóe à História e ao Sistema da Arte hegemônicos, ao mesmo tempo que contribui para uma revisão de suas práticas discursivas de inclusão e exclusão, por meio de sua poiesis, sua fabulação poética, na qual a um só tempo se visita e se reinventa uma ancestralidade afroindígena, atinente às origens e religiosidade da artista. A aparição e a visão do corpo preto e dissidente de Castiel apontam para uma desestabilização do que Hubert Damisch nomeará "o teatro da representação". Teoricamente, este texto recorre a um campo caracterizado pela interdisciplinaridade, no intuito de responder à complexidade de seu objeto de eleição: teorias decoloniais, estudos de gênero, teoria queer, filosofia, teoria lacaniana, teoria e história da arte, o que o aproximaria daquilo que a teórica holandesa Mieke Bal denomina Análise Cultural.

Palavras-chave: Gênero. Corpo. Negritude. Análise Cultural. Teoria e História da Arte.

\section{INTRODUÇÁO}

Pensar os vieses que comandam a hegemonia do Sistema da Arte (BULHÓES, 2014), esse conjunto de forças, as quais, integradas, formam um campo tensional, cujas relaçóes internas determinam a lógica de seu funcionamento, precisa, em nosso entender, partir da análise de práticas artísticas em que o que se nomeou, no campo das artes visuais, "crítica

${ }_{1}$ Professor Substituto do Programa de Graduação em Artes Visuais, na área de Teoria e História da Arte, do Instituto de Artes da Universidade Federal de Uberlândia (UFU), Uberlândia, MG - Brasil. (D) https://orcid.org/0000-0002-3178-646X. E-mail: marcoantoniorvieira@gmail.com.

https://doi.org/10.1590/0101-3173.2022.v45esp.14.p265

\section{(i)}


institucional" (FOSTER et al., 2011, p. 668-673), se possa conceber como efeito de significação da obra analisada.

É a condição mesma do corpo-obra da artista Castiel Vitorino Brasileiro, em que se instaura todo um aparato semiótico-discursivo a questionar a História da Arte e suas políticas de exclusão, que nos mobiliza aqui. A potência desestabilizadora da poiesis de Castiel depende das tensóes dissidentes oriundas da historicidade da "[...] arquitetura política e jurídica do colonialismo patriarcal, da diferença sexual.” (PRECIADO, 2020, p. 31). Não é outro o locus em que se instalam visíveis, óticos, ou, como os define Jacques Lacan, "escópicos" (objetos do olhar) (1996), os signos que convertem o corpo discursivamente tramado de Castiel Vitorino Brasileiro em objeto de investimentos que o sentenciam à subalternidade silenciada e marginalizada (SPIVAK, 2010) de um sistema que é igualmente réplica e reprodução das reiteraçóes excludentes, associadas à história desse corpo, que o colonizam como objeto olhado e objetificado pelas engrenagens e mecanismos de funcionamento deste sistema e desta história.

Nossa perspectiva teórica é interdisciplinar e recorre às contribuiçôes de um terreno no qual se cruzam elementos da teoria lacaniana, da filosofia de Jacques Derrida, dos estudos de gênero, da teoria queer, da decolonialidade, da teoria e da história da arte. Parte-se ainda de uma problematização do campo historiográfico, na medida em que se reflete acerca daquilo que se compreende como "ficção", em razão do giro ou virada linguísticos das décadas de 60 e 70 do século XX, cujo impacto sobre a disciplina histórica foi considerável, naquilo que sua dimensão de escritura encerra como a narratividade fabricada no espaço do texto e afeta a compreensão do passado ${ }^{2}$, a partir de como se o olha, uma mirada analítica autorizada e viabilizada pelo que Mieke Bal definirá como "[...] the critic's situatedness in the present"(BAL, 1999, p. 1), o que se poderia traduzir a um só tempo como a "situação" e/ou "localização" presente do crítico.

A rigor, estamos diante de "uma memória cultural no presente", o que inevitavelmente desembocará em uma relação ambivalente com a história. Tal ambivalência acaba por aproximar, em que pesem suas inegáveis distinções,

${ }^{2}$ Ver, por exemplo, WHITE, Hayden. Trópicos do discurso - ensaios sobre a crítica da cultura. Ttradução de Alípio Correia de Franca Neto. 2. ed. 1. reimpr. São Paulo: EDUSP, 2014; RICOEUR, Paul. A memória, a história, o esquecimento. Traduçấo de Alain François. Campinas: UNICAMP, 2000/2007; CERTEAU, Michel de. História e psicanálise - entre ciência e ficção. Tradução de Guilherme João de Freitas Teixeira. 2.. ed. Belo Horizonte: Autêntica, 1987/2011; LIMA, Luiz Costa. História, fiçaão, literatura. São Paulo: Companhia das Letras, 2006. 
nossa abordagem teórica da maneira como a artista de que se ocupa este texto ressignifica elementos de uma ancestralidade mítica e pretérita no espaço poético de sua obra. O "passado" é então percebido a partir de suas sobrevivências - Nachleben - fantasmáticas (WARBURG, 2014), a assombrar e perturbar a ilusória fixidez de suas representaçóes, como que incrustadas naquilo que se dá a ver dessa passeidade (RICOEUR, 2007).

Ora, se o "passado", que resulta de uma tal perspectiva metodológica, em nosso texto, ou poética, no que tange à obra de Castiel Vitorino Brasileiro, surge "impuro" e, em larga medida, em permanente processo de construçáo, parece-nos legítimo que a interdisciplinaridade, a caracterizar o que Bal entende por Análise Cultural, possa refletir-se na aparente bastardia que marca a pletora de recursos de que aqui nos valemos, para que essa "terceira pessoa" (BAL, 1999, p. 8) - o objeto de que fala o texto e que Mieke Bal reputa como o mais central na tríade discursivo-comunicacional descrita em seu texto possa emergir, em sua criticalidade.

Há uma ética do dizer a atravessar esse circuito tripartite: entre a "primeira pessoa", o sujeito que escreve, e a "segunda pessoa", aquela a ler-nos o texto, deve interpor-se e advir essa figura sob a forma de escrutínio crítico, essa "terceira pessoa", a qual oscila perpétua entre um universo autocontido e uma trama arborescente de veios em que circulam sentidos incessantemente, sem que se possa estancar o fluxo de significação que identifica e complexifica a tensão entre "coisa" e "signo", que caracteriza o exercício analítico.

A impossibilidade de esgotar esse objeto ou "terceira pessoa", como nos ensina Mieke Bal, é o que náo apenas comanda a aproximação interdisciplinar que aqui se adota, mas que também se apresenta, para nós, como uma posição a um só tempo crítica e ética diante desse circuito discursivo defendido por Bal e que nos serve como posicionamento teórico-metodológico. Ademais, é do "corpo" e do "corpo como obra" de que se trata, neste texto, e seus limites discursivos constituem um real desafio para o pensamento.

Daí que se possa pensar, ao se analisar esse corpo dissidente, como o definirá Paul B. Preciado (2020), apenas e tão somente desde o momento no qual, dentro do enquadramento teórico que nos permite olhá-lo, muito daquilo que se ergueu criticamente para lidar com a arte ocidental imploda e aponte para um além da representação clássica, deixando-nos em seu rastro, os escombros a partir dos quais se contemplam sua potência de ressignificação e as ruínas de um sistema ameaçado, em múltiplos sentidos, pela existência 
mesma, assim como pela inserção, embora limítrofe, do corpo-obra de Castiel Vitorino Brasileiro, nas margens de suas fronteiras, de seus longamente cerceados territórios, verdadeiras zonas de monopólio e poder.

\section{O CORPO COMO LOCUS E TOPOS DA HISTÓRIA DA ARTE HEGEMÔNICA}

Lugar de acontecimentos fisiológicos, medida da vida e da morte, o corpo é a arena em que trocam olhares Eros e Thanatos. Que sexo e morte se entrelacem de tal maneira indissociáveis, nesse complexo terreno cuja existência e funcionamento aparentam oscilar entre a autonomia maquínica e as tentativas de disciplinar, subordinar e protocolar aquilo que do corpo se autoriza ver, é o que nos mobiliza o olhar aqui.

Que o corpo se converta então em um conjunto de encenaçóes que hesitam entre mostração (MARIN, 2001, p. 37) e ocultação, entre a pele e o que ela esconde, é o que nos interessa aqui. Ao pensar assim, o corpo aparenta assumir muito de sua consistência ontológica, em vista de uma cisão constitutiva entre o ver e a sua interdição. Uma tal aporia só poderia emprestar ao corpo sua potência tropológica e figurativa (DIDI-HUBERMAN, 2015, p. 43), e não é de outro lugar tampouco que se extrai sua centralidade para uma história na qual se cruzam os mais variados discursos, da medicina às artes, do que nos dão prova os estreitos vínculos entre a anatomia e sua iconografia (MANDRESSI, 2005, p. 411-440), por exemplo.

No caso das artes visuais, a migração de objeto da representação para agente mesmo da performance, em que suporte e obra adquirem uma outra espécie de imbricação para a qual a ação do corpo se escande, em sua significação na duraçáo da performance, esse corpo/suporte/agente/obra é aquele que se resolve temporalmente na performance. Toda a relação com o tempo, durante longo tempo considerada um apanágio literário, torna-se uma reivindicação da pintura, desde o Renascimento. Entretanto, no que tange à performance, esse "tempo" é a obra: corpo-tempo da performance.

Nesse sentido, a operação - chamemo-la assim - performática transcende a demarcação meramente representacional atinente ao pictórico, já que sua inferência só se poderia dar dentro dos domínios que a espacialidade da pintura permitia conter e dar a ver. $\mathrm{O}$ tempo era o objeto de uma dedução que cabia à potência morfológica da figuração. Cabe, todavia, a persistência do compartilhamento da ação, ou seja, a narratividade e/ou os sentidos da obra 
que se desenrolam no tempo e que, tanto em uma como outra linguagem, se desencadeiam a partir do corpo, ainda que se observem as especificidades inerentes à pintura e à performance.

Palco dos binarismos mais estruturantes para o pensamento ocidental - corpo e alma, vida e morte - a, o corpo, se nada mais, aloja a lógica binária e logofonocêntrica dos sexos. O corpo-poético e performático da artista negra e travesti Castiel Vitorino Brasileiro forneceu-nos material reflexivo para uma análise das implicaçôes epistêmicas para o questionamento de uma História da Arte hegemônica. A ontologia mesma de seu corpo, no qual gênero e raça complexificam sua posição como sujeito, artista e obra, constitui o desafio teórico de que se ocupa este texto.

O corpo aparenta operar no limite do (im)pensável, o que, para Jacques Derrida, é o limite, a "passagem" mesma pela qual a filosofia opera (DERRIDA, 1991, p. 11-12), ou, como o expressa Judith Butler, especificamente acerca do corpo como questão para a Filosofia: "Teorizar a partir das ruínas do logos convida à seguinte pergunta: 'E quanto à materialidade do corpo?'." (BUTLER, 2019, p. 9).

É a partir dessa injunção limítrofe, em que desejo e resistência parecem coexistir, que a obra-corpo ou corpo-obra de Castiel Vitorino Brasileiro aparenta articular-se tripartite, como desafio, enigma e proposição, para a hegemonia das práticas de representação que convertem o terreno em que circula a arte contemporânea no Brasil em um campo de tensôes e disputas simbólicas.

O corpo, pois, como se o pensa aqui, reúne em sua superfície e tornase locus de investimentos calcados em sua condição de objeto visível, uma complexidade que acaba por conceder-lhe a potência retórica de que partimos para o tratarmos como topos, ou seja, um terreno em função do qual toda uma arquitetura retórica se ergue, dada sua inegável centralidade para a compreensão do sujeito de seu lugar no mundo. Outrossim, como o frisamos alhures, neste texto, é a partir daquilo que seu corpo encerra como objeto de uma ocularização que Castiel desafia e afronta o sistema da arte e do binarismo constitutivo e estruturante do sistema sexo-corpo-gênero.

\subsection{O CORPO E O DESMONTE EINSTEINIANO DO MODELO PICTÓRICO OCIDENTAL}

O lugar central que ocupa o corpo, no sistema representacional ocidental, ancora-se em uma aparente teleologia, a qual se materializa no 
percurso naturalista que consagra o modelo mimético a triunfar na escultura clássica grega e na pintura muralista da Roma Antiga, vê-se grandemente elidido durante boa parte do Medievo, para então constituir-se como uma das pedras de toque do modelo pictórico a comandar a Renascença e a Idade Clássica da Representação, a vigorar do século XVI ao XVIII. Certamente, poder-se-ia escrever uma História da Arte Ocidental tendo no corpo seu significante e sua figura mais determinantes naquilo que o corpo encerra como medida exitosa do mimetismo naturalista.

O substrato morfológico a presidir a lógica representacional da Arte Ocidental caracterizou-se, portanto, por sua potência retórica de fornecer "simulacros" suficientemente críveis do corpo humano. O sujeito vidente via-se enredado, capturado, fisgado pela sedução de tal naturalismo e suas configuraçôes sintáticas. A istoria, vocábulo latino que significa "[...] a composição de figuras humanas engajadas em uma ação" (ARASSE, 2005, p. 537), era calcada na arquitetura figurativa de extração naturalista em que o referente (o corpo "real") precisa duplicar-se crível no representante (sua representação, por meio do desenho e da cor) da pintura.

Negerplastik, de Carl Einstein (2011), propõe um determinante desnudamento do esqueleto representacional e discursivo ocidental, a partir do desmonte do modelo pictórico vigente no Ocidente. Sua argumentação, ao demonstrar o quão dependente do ângulo de visão monocular e soberana que organiza a representação e sua respectiva sintaxe, transcende os limites normalmente associados ao campo de saber nomeado História da Arte, para denunciar todo um aparato que encarna um determinado modo de ver, o qual se articula ao próprio modo de conceber, organizar e julgar o mundo, no Ocidente. Estamos diante de uma verdadeira episteme visual.

A materialização artística acomoda, assim, nas malhas do que se convencionou chamar "estético", as colonizaçôes discursivas que comandam as imagens em que se reconhece o sujeito ocidental. $\mathrm{O}$ texto einsteiniano logra ainda dissipar qualquer ilusão de superioridade artística encerrada pelo modelo pictórico ocidental, em relação à arte africana, o qual, segundo o autor, encampa igualmente a concepção escultórica no Ocidente.

Para Einstein, as esculturas e máscaras africanas sugerem um modo inteiramente outro de "visão". Em vez de uma concepção monocular, calcada no sujeito da visão que organiza o campo da representação, a arte africana não se confirma na lógica duplicativa de um referente a confundir-se com 
o representante. Essa outra forma de conceber aquilo que no ocidente se nomeia "arte", advém, na Arte Africana, de uma concepção religiosa que não contempla uma duplicação especular entre a criação e seu criador, fundamento basilar do Cristianismo.

As máscaras e esculturas africanas possuem, nesse sentido, uma autonomia morfológica que não encontra eco no modelo pictórico da arte ocidental, como o descreve o texto de Carl Einstein. A compreensão de que uma tal morfologia nasce a partir de uma outra e legítima perspectiva civilizatória invalidaria por completo o rebaixamento da arte africana, pois a pretensa "universalidade" do modelo pictórico descrito pelo texto einsteiniano se interpreta aqui inequívoca, com base na estrutura argumentativa de Negerplastik como uma "ficção" totalitária - "universal" "branca" e ocidental, em tudo atinente ao cálculo discursivo do regime colonialista e escravocrata, como nos lembra Achille Mbembe:

A raça não passa de uma ficção útil, uma construção fantasmática ou uma projeção ideológica, cuja função é desviar a atenção de conflitos considerados, sob outro ponto de vista, como mais genuínos- a luta de classes ou a luta de sexos, por exemplo [...] Em sua ávida necessidade de mitos destinados a fundamentar seu poder, o hemisfério ocidental considerava-se o centro do globo, a terra natal da razão, da vida universal e da verdade da humanidade. (MBEMBE, 2018a, p. 29).

A centralidade do corpo como "figura" - a um só tempo, "[...] um corpo ou sua forma e uma figura retórica do discurso" (BAXANDALL, 2018, p. 43), é-nos aqui instrumental. Tal termo serve a um só tempo à lógica da compositio - composição - pictórica da cena responsável pela narrativa que se apresenta na pintura, quanto à tropologia. É contra esse pano de fundo que, cremos, a reflexão em torno da "negritude" nos regimes de visualidade e discursividade ocidentais precisa destacar-se.

O corpo negro que nasce da poiesis de Castiel Vitorino Brasileiro, artista negra e travesti, torna-se, em nossa leitura, uma figura outra, pois surge da elaboração poética de Castiel. Ainda que se abisme na radicalidade figural, porque sua inscrição se dá como permanente rasura - "[...] nunca cessa de não se escrever" (LACAN, 1975, p. 120) -, o enigma de seu corpo oferece resistência e sedução à leitura, o que se desdobra em resistência à acomodação mesma de sua produção, no Sistema da Arte contemporânea. 
Sua obra aparenta ecoar o laborioso exercício de desfiar o tecido do campo discursivo circunscrito pela História da Arte, na visada feminista de Griselda Pollock, por uma operação à margem que assume a forma de "intervençôes" que se dão, como insiste Pollock, "fora da História da Arte":

Acrescentar mulheres à História da Arte equivale a produzir uma História da Arte feminista? Exigir que as mulheres sejam levadas em consideração não apenas altera o que se estuda e o que se torna relevante para a investigação, mas questiona as disciplinas existentes politicamente. (POLLOCK, 2003, p. 1, tradução nossa).

A marginalidade em relação ao Sistema das Artes opera invariavelmente a partir das fissuras históricas sob a forma de invisibilidade de corpos destoantes, no que concerne não apenas ao gênero, mas igualmente à raça. É o que a desoladora obra do artista Sidney Amaral (1973-2017), O estrangeiro, de 2011, denuncia, ao inserir uma personagem negra - o próprio artista - a navegar as turvas e negras águas que cobrem parte das fundações do Pavilhão do Ibirapuera, sede da Bienal de São Paulo. O artista rema solitário nessa cena em que a sintaxe cromática da obra se estrutura, a partir do par branco/preto, ao qual a "ficção" racial aderiu historicamente.

Figura I: Sidney Amaral (1973-2017) - O estrangeiro, 2011

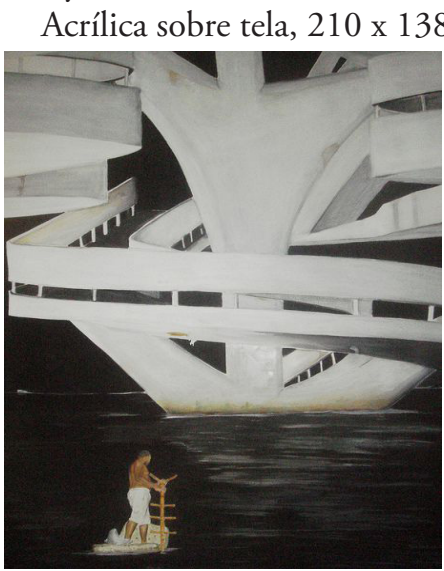

Fonte: https://projetoafro.com/artista/sidney-amaral/ 
A branquidão monumental da arquitetura modernista contrasta com a escuridão das águas sobre as quais paira o corpo negro do artista vestido de branco, em uma diminuta canoa. Seu remo assemelha-se ao tridente de Exu, orixá que é o elo de comunicação dos humanos com a divindade. Exu, portanto, é passagem: e que essa obra se ampare nessa cena em tudo onírica, na qual o artista enfrenta a opacidade das águas, como um artista cujo corpo marcado negro carrega uma história de banimentos do Sistema das Artes, não é fortuito.

Exu tende a ser o mais incompreendido dos orixás africanos. A doxa em torno da divindade o sentencia a analogias insustentáveis com a figura do demônio cristão. Tal incompreensão e intraduzibilidade são, assim como as fundações arquitetônicas a figurar em $O$ estrangeiro, invisíveis, embora as saibamos sólidas a sustentar o edifício de prescriçóes e proscriçôes que estruturam o Sistema das Artes e condenam o "negro" a uma marginalidade subalterna. A subsunção do corpo negro a um sistema que carrega as marcas da mesmidade da "cultura suprematista branca" (HOOKS, 2019, p. 26) é denunciada pelo historiador da arte nigeriano Olu Oguibe:

Pré-História. História. Pós-História. É prova da arrogância da cultura e discurso ocidentais que o próprio conceito de história se converta em uma colônia cujas fronteiras, validaçóes, estruturas e configuraçóes, mesmo a propriedade da vida sejam única e integralmente decididos pelo Ocidente. Desse modo, a história é construída como um privilégio legitimador cuja outorga cabe ao Ocidente [...] Pré-modernismo. Modernismo. Pós-modernismo. É tentador insistir na negação da modernidade à África ou outras culturas que não a ocidental. (OGUIBE, 1993, p. 3-4, tradução nossa).

A subalternidade periférica denunciada pela obra de Sidney Amaral e pelo texto de Olu Oguibe não deixa outra alternativa ao corpo negro que uma (re)invenção radical de sua história e representaçôes, como alerta bell hooks:

De fato, uma tarefa fundamental dos pensadores negros críticos tem sido a luta para romper com os modelos hegemônicos de ver, pensar e ser que bloqueiam nossa capacidade de nos vermos em outra perspectiva, nos imaginarmos, nos descrevermos e nos invertamos de modos que sejam libertadores [...] Desafiados a repensar, artistas e intelectuais negros insurgentes buscam novas formas de escrever e falar sobre raça e representação, trabalhando para transformar a imagem. (HOOKS, p. 32-33).

A consciência das consequências para a inserção da radicalidade poético-política de seu trabalho, no Sistema das Artes, no Brasil, leva Castiel 
Vitorino a ponderar: "Não existe democracia no Brasil e o sistema das artes na contemporaneidade é neoliberalista. A 'democratização' da arte é uma demanda de desmonte da estrutura racista e travestifóbica que é a nação brasileira [...]" (BRASILEIRO, 2020, p. 235).

Compreende-se aqui a História da Arte como um conjunto de narrativas ideologicamente tramadas, calcadas em um modelo prescritivo, no interior do qual se fabricam verdades que acabam por calcificar representação e referencialidade, promovendo uma adesão dos conteúdos a serem veiculados às configuraçôes morfológicas - formais - encarregadas de escrever as histórias em que o sujeito da representação se reconhece.

O "mundo" é, assim, o efeito desse compêndio de representações, e as representaçôes que triunfam são aquelas regidas pelo cálculo colonialista da supremacia branca heteronormativa e cisgênere, as quais assumem a consistência sensível de realidade, pela naturalização, difusão e reiteração das reverberações desse verdadeiro aparato ideológico, cujo domínio não se sustenta apenas como imposição exterior, todavia, sobretudo como colonização inconsciente que se infiltra, tão mais eficiente por encontrar-se encoberto "de verdade" e agindo a um só tempo sobre os dispositivos imagéticos e textuais e sobre os corpos que integram esse mundo que se fabrica a partir da alegada e suposta neutralidade universal branca e não apenas hétero, mas cisnormativa.

\section{CASTIEl E A IMPLOSÃo do TEATRO DA REPRESENTAÇÃo}

Poiesis: com a aparição desse corpo negro a carregar um compêndio de histórias que se perdem na noite dos tempos, só o compreendemos, em nossa clausura epistêmica, como o corpo de um nascimento. Corpo de uma "invenção", a que o vocábulo grego alude e cuja obra fotográfica, de 2019, Quando criei minha origem, de Castiel Vitorino, parece confirmar. Nela se veem fotos da artista ao lado de um indígena brasileiro e de seu avô. Ali, as origens afroindígenas da artista tramam-se, em vista de uma ancestralidade a um só tempo imemorial, mítica e familiar.

Corpo que, em sua radicalidade em perpétuo por vir, é o corpo da différance (DERRIDA, 1995). Corpo diferido, cuja significação última é permanentemente adiada. Sua definição, dentro das grades que o aprisionariam na arquitetura figural do logofonocentrismo ocidental, encontra-se fadada ao malogro de uma incompreensão desde sempre instrumentalizada a foracluir termo psicanalítico que significa banir, proscrever, expulsar e expelir - como 
indigno de "representação". Pois que seja então justamente sua condição de "irrepresentabilidade" que o torna abjeto, ob-ceno — ausente, fora da cena -, o mote mesmo de sua condição periférica, marginal. Corpo sem inscrição dentro desses limites ou clausuras representacionais.

Como assinalado anteriormente, o corpo opera, para o pensamento, no limite do (im)pensável: "[...] descobri que não poderia fixar corpos como simples objetos do pensamento.” (BUTLER, 2019, p. 9). Uma vez que o corpo de Castiel Vitorino é a um só tempo o agente de sua obra em que se confundem os motivos de uma poética e de uma existência, pareceunos legítimo o exercício de o abordar, em razão de uma espécie de tensão fronteiriça entre representação e aparição, no intuito de que se o possa pensar em relação ao que as estruturas discursivas e representacionais da História da Arte lhe reservaram.

"Aparição" aqui é o que se retira da origem mítica do teatro, em que o deus mesmo se mostrava em "plena luz" (HARTOG, 2011, p. 12). O rito que se encontra na origem do teatro, por meio da invocação, demandava que o deus se apresentasse em sua luminescência. Com o passar do tempo, substituise a aparição divina por sua "aparência". Essa passagem que nasce do rito e dele migra para uma encenaçáo, na qual impera a suspensão da descrença calcada no jogo das aparências é o que constitui a engrenagem retórica teatral: sugerese uma aparição. Eis a economia simbólica aqui encerrada. Segundo a análise de Carl Einstein, a arte africana opera sob outro regime gnóstico, um outro "saber teológico", em que não há aproximação duplicativa entre o incriado (Deus) cristão e sua criação humana.

Que se pense a performance nas artes visuais como essa zona limítrofe entre o teatro e a pintura: a cena é onde eles se encontram, como se explorará mais detalhadamente adiante, a partir de uma proposição de Hubert Damisch (1972). Essa cena que se resolve na temporalidade da performance é o "lugar" do nascimento de Castiel Vitorino Brasileiro e onde se entrelaçam os motivos de uma existência e sua consistência poética. E que à "cena teórica”, que ora propomos, se possa, ao modelo pictórico ocidental desnudado em Einstein, contrapor simultânea a plasticidade destacada por Einstein nas máscaras e esculturas africanas, em sua relação destituída do vínculo mimético de cepa naturalista que impera na picturalidade eurocêntrica.

Seria insustentável supor que o corpo da performance se possa encontrar destituído de investimentos representacionais, uma vez que o corpo-obra de Castiel se "oferece" à leitura: "Ler é primeiramente, reconhecer 
uma estrutura de significância: que tal forma, tal figura, tal traço é um signo, que ele representa alguma outra coisa, sem que saibamos necessariamente qual é essa outra coisa representada." (MARIN, 2001, p. 20). Que inexista uma "inscrição" referencial estável o bastante para satisfatoriamente "representar" não equivale à desistência por parte do sujeito vidente, sujeito da interpretação, de proceder à elaboração interpretativa dos índices sígnicos à sua disposição. ${ }^{3}$

Para nós, o que Castiel Vitorino propóe como poiesis se fabula com base em uma espécie de ficçáo performativa do rito da aparição de um corpo, cuja criação se dá em uma fronteira de tensôes entre o ritual invocatório e sua potência representacional, na qual se conjugam sua ancestralidade afroindígena e seu corpo travesti e se alimenta da própria história familiar da artista e de sua linhagem, como iniciados na religiosidade de matriz africana.

O que Castiel fabrica equivale a um batismo a um só tempo artístico e existencial. Seu corpo ritualizado conclama sua invenção poética como a legitimação mesma de um corpo em que "Castiel" vem ao mundo em "plena luz". Castiel, é importante que se ressalte, é o nome de um arcanjo e se trata de um nome teofórico, ou seja, um nome próprio que contém um nome de um deus e, simultaneamente, serve como difusão do nome sacro como para invocar a proteção da qual se investe o corpo assim nomeado.

No intuito de sustentar a lógica argumentativa que ora se propóe, recorre-se à aproximação entre a cena teatral e a pictórica, apresentada por Hubert Damisch, naquilo que, como se deslinda em sua argumentação, o teatro e a pintura se irmanam, a saber, a estrutura representacional como se a concebia até o século XVII:

Se a representação, no sentido discursivo do termo, se deixa levar, no contexto da epistemologia clássica, a um jogo de substituiçôes fundado sobre a reciprocidade do significante e do significado (como se diz na Logique de Port-Royal) e da coisa representada, as relaçóes ambíguas que a arte terá mantido com o espetáculo, por um longo tempo antes do século XVII, não são um indício de um parentesco secreto entre os dois modos de representação? Que se passa com efeito com a pintura, uma vez que ela se dá por uma representação, e pelo equivalente ou substituto de um espetáculo do qual ela toma emprestada parte de seus meios, mas que não será sem por sua vez alegar imitar a vida, mesmo pintar as paixốes? E o que dizer da própria representação, se o discursivo e o espetacular, longe de se excluírem, podem ligar-se e conjugar-se sobre o palco do teatro, assim como sobre o plano da tela? (DAMISCH, 1972, p. 91, traduçáo nossa).

3 A complexidade do reconhecimento embutido na "recepção" do corpo transgênere é desenvolvida por Leal (2018). 
Tal apresentação do enquadramento representacional configurase sobretudo como uma encenação - colocação em imagens - em que suas personagens se instalam em um palco - lugar de visualidade e visibilidade no qual se desenrola um teatro que alegoriza a representação. O século XVII é o século do Barroco: o século da teatralidade, por excelência. Theatrum, que etimologicamente se articula como "lugar de onde se vê", é a alegoria que acaba por estruturar nossa interpretação da poética de Castiel. É também de uma alegorização em tudo teatral que o corpo de Castiel Vitorino se inventa, diante de nosso olhar. É no "ver" que se confirmam "representacionais", para a lógica do "ver" seiscentista, o teatral e o pictórico.

E não nos deveria tampouco causar espécie que seja desse modelo em que impera o "ver" a partir do que se dá como encenação no modelo de visualidade que autoriza o palco italiano, no qual e estruturará todo o arcabouço representacional pictórico renascentista e suas mutações - a um só tempo desdobramento e desfiguração - no Barroco que o sucede. É na circunscrição espacial que instaura o modelo do "ver" pictórico que se confirma o teatro do "ver" da Renascença. É fundamental que se esclareça aqui que aquilo que nos interessa se deve enxergar como uma analogia.

A imagem de um palco italiano em sua potência de espetacularização ótica, levada ao paroxismo no Barroco histórico, em que a ilusão confeccionada pelo artífice conduz a uma impossibilidade de distinguir representante (significante) e representado/referente (significado), não por meio de uma clareza demarcatória, como no caso da arte renascentista, porém, de um investimento de extração passional obtido pela explícita manipulação retórica - compartilhada a um só tempo pelo teatro e pela pintura - é o que se torna aqui instrumental.

Em Damisch, a mise em abyme, em que a lógica da representação se converte no objeto da própria representação - uma espécie de "miragem" da metalinguagem impossível como linguagem-objeto, a qual nunca se poderá arvorar a instância do "para-além da linguagem" -, é invocada em seu texto, ao referir-se à "encenação dentro da encenação", a "cena dentro da cena" que se encontra no centro da trama de Hamlet (c. 1600), de William Shakespeare (1564-1616), peça na qual, para apanhar na "armadilha" do olhar o tio assassino, segundo a fantasia hamletiana que lhe é "revelada" por um fantasma, Hamlet encena o assassinato paterno segundo a imagem que lhe oferece o fantasma do pai. São as reverberaçóes da encenação, dessa mostração, que desencadeiam o encaminhamento final da peça. A encenação hamletiana 
da morte do pai é o deus ex machina da peça de William Shakespeare. Dirá Hubert Damisch (1972, p. 93, tradução nossa):

\begin{abstract}
É assim que se passa no teatro, quando, no interior da representação, se instaura uma segunda representaçáo, segundo a qual uma parte dos atores sáo convidados a participar - teatro dentro do teatro, cujo modelo permanece aquele da encenação de Hamlet a seus próximos -; pode parecer que por efeito desse encaixe/encaixotamento de uma cena dentro de outra, a representaçáo exercita-se no sentido de destruir-se, pelo menos de denunciar a si mesma como representaçáo: o que é dado a ver ao público não é mais uma representação, mas a representação de uma representação, e que deveria bastar a si mesma, caso a representação, em sua essência, se pudesse reduzir à produçấo de um espetáculo.
\end{abstract}

A esse aparente paradoxo representacional, Damisch nos recorda que a representação pictórica nunca se ateve exclusivamente à "ordem natural das aparências sensíveis", entretanto, sobretudo, à “[...] ordem instituída do espetáculo que a cultura oferece à si própria, sob as mais variadas espécies".

A representaçáo, dentro do enquadramento teórico que se delineou ao longo deste texto, replica assim a própria lógica da linguagem e, mais especificamente, da alegoria como um construto que dá a ver não exatamente e apenas a narrativa subjacente ao encantamento alegórico, mas, antes, desnuda o esqueleto do próprio funcionamento da linguagem. Damisch afirma categoricamente que a representação, ao denunciar-se como tal, acaba por "destruir-se". É a essa implosão que as performances de Castiel Vitorino parecem filiar-se, nessa fronteira que hesita entre o teatral e o pictórico, como nos propôe Hubert Damisch.

\title{
1.3 Castiel E O GOZO TRÁGICO E TRAVESTI DE UM CORPO-FLOR
}

Castiel Vitorino encarna, em sua radicalidade propositiva, o estético, o existencial e o político. Seu corpo-obra converte-se em uma arena para trânsitos que abalam as noçóes engessadas de identidade sexual e de gênero que se alojam no corpo e dele se desprendem em efeitos, o que se poderia pensar a partir de uma espécie de versão atualizada da teoria dos affetti, ou Affektenlehere (HARNONCOURT,1988), na qual haveria uma morfologia a encarnar sintaticamente as paixóes - pathemata. 
O corpo de Castiel surge, por conseguinte, em sua inequívoca singularidade e não apenas como um "tipo" viabilizado visualmente por uma determinada técnica ou tradição iconográfica em que se deposita o legado do repertório expressivo e representacional da História da Arte Ocidental, em seus academismos aprisionadores e engessadores: o negro como nada senão uma ficção branca, a partir do prisma da mesmidade em que o "outro" é objeto de violências que sentenciam seu corpo à vulnerabilidade exploratória e genocida, mas igualmente à subsunção representacional desse corpo.

Um corpo, cujo representante se investe de afetos e que, dada a retoricidade naturalista que o consagra como morfologia a triunfar no Ocidente, passa a valer como verdade. Logo, o referente se torna aqui dispensável, em sua consistência real.

A insistência nessa historicidade espectral é tão apenas um modo de vislumbrar a radicalidade desse corpo, em sua potência e impacto catárticos, também como objetos do visível e do olhar, já que há uma inegável visualidade que o envolve e apresenta ao olhar interpretativo no qual se identificam signos que facilmente poderiam remeter à História da Arte, mesmo com o intuito de desestabilizá-la, como no caso da performance de 2019, Macete para crescer peito, que se analisará com mais pormenores adiante, em que a artista procede, em nossa leitura, a uma remissão paródica ao gênero pictórico das naturezas-mortas.

O recurso a essa história se legitima, de vez que o corpo-obra de Castiel Vitorino Brasileiro, em que pese sua marginalidade periférica, ao integrar circuitos e plataformas, as quais veiculam sua atuação como artista, inevitavelmente reclama um lugar nessa História e Sistema das Artes, nem que sob a forma de "intervençóes" externas ao círculo dessas pertenças sistêmicas, como o expressa Griselda Pollock (2003).

A Castiel que nasce de sua fabulação artística oscila perpétua entre a vida e a morte, como uma espécie de Antígona afro-brasileira, pois, como nos instrui Judith Butler, seu corpo, em que enxergamos "Antígona”, tensiona exemplar e dolorosamente as regras subsumidas pelo "Estado" e os sujeitos desejantes que se expressam por meio de práticas sociais desestabilizadoras, as quais desafiam a ordem imposta pela supremacia cisnormativa (ordem calcada na instrumentalizaçáo discursiva do "sexo biológico" designado no nascimento), branca e patriarcal (LEAL, 2018). Seu corpo, ao enfrentar e afrontar a ordem suprematista, ao mesmo tempo que afirma veemente a vida, 
arrisca-se como alvo seletivo do silenciamento e extermínios a que as práticas genocidas denunciadas por Achille Mbembe (2018b) condenam populaçóes vulneráveis, no Brasil.

Como uma espécie de Antígona, Castiel Vitorino vive a radicalidade trágica e gozosa de seu desejo. Em seu texto Clamor de Antígona, Butler apresenta a personagem da tragédia de Sófocles a partir de uma interpretação de problematizaçâo de gênero, em que a resistência de Antígona em desrespeitar a ordem instituída por seu tio, Creonte, ao negar um enterro digno para seu irmão, Polinices, é vista como uma transgressão por parte de uma mulher. "Curiosamente, tanto o ato de enterrar quanto a rebeldia verbal de Antígona tornam-se ocasióes em que ela é considerada 'masculina' pelo coro, por Creonte e pelos mensageiros. De fato, Creonte, escandalizado por tal rebeldia, decide que, enquanto viver, 'nenhuma mulher deve governar, sugerindo que, se ela governar, ele morrerá.” (BUTLER, 2014, p. 27).

É inegável o fato de a obra de Castiel Vitorino Brasileiro emprestar tamanho protagonismo à complexidade que seu corpo encerra, no que diz respeito à encruzilhada que nele se instala, a partir de como sexo, gênero e raça ali se imbricam como identidades, as quais, histórica e estruturalmente, se marginalizaram no Brasil, de sorte que sua condição ontológica implica um posicionamento político diante da tragicidade que a assunção de uma tal identidade possa representar para as práticas necropolíticas (MBEMBE, 2018-b) de extermínio e genocídio das populaçôes racializadas e vulneráveis (NASCIMENTO, 2016) e dos dissidentes sexuais e "desobedientes de gênero" (MOMBAÇA, 2021) que caracterizam nossa história.

Que seja esse corpo não apenas aquele que inspira compaixão, mas igualmente e, sobretudo, como no caso de Castiel, aquele que encara de frente seu algoz e desafia afrontosamente a ordem na qual seu poder se ancora em aparatos imagético-discursivos que insistem em excluir todo o corpo desviante da lógica suprematista e dominante, é o que indubitavelmente faz com que Castiel Vitorino se aproxime da figura trágica de Antígona.

Castiel invoca sua ancestralidade afroindígena de feitiçarias e pajelanças. Ao torná-las "suas", alcunha-as de "macumbarias" e opera, portanto, em uma zona litoral entre a religião e a arte, à maneira de seus antepassados, em que pese a radicalidade autoral de sua abordagem da ritualística e mitologia africanas. Como uma boa parte dos artistas que se identificam em função de uma identidade negra ou "de cor", "não branca", Castiel recorre ao que 
Édouard Glissant (2013, p. 18) nomeia uma recomposição por meio de "rastros e resíduos" de um passado mítico que se eclipsa no processo colonialista e escravocrata, no qual o corpo africano é desterrado para a criação da América Negra e muito de sua história é condenada ao esquecimento.

É ainda de Glissant que se toma de empréstimo o termo "crioulização" (2013, p. 19-27), que se distingue de mestiçagem ou hibridismo, pois, segundo o autor, seu cálculo final é marcado pela imprevisibilidade. Em Castiel Vitorino, o "rito" artístico e poético, embora se ampare em uma tradição daquilo que Y. V. Mudimbe entende por gnose (1988), ou seja, um saber que não se confunde com a filosofia ocidental, por exemplo, serve à fabricação de uma obra que não apenas recusa uma separação nítida da vida, mas também reclama seu lugar fundante à margem do Sistema das Artes contemporâneo. $\mathrm{O}$ resultado é, portanto, crioulizado.

À “identidade" fixa e imutável, ela também um cálculo estratégico tramado no interior de concepçóes fascistas do mundo, em que a noção de "pureza identitária" é instrumentalizada politicamente, para fins de dominação e extermínio, questionada pela crioulização, segundo Glissant, sobrevém uma identidade poética em construçâo. Para Stuart Hall (2013), as identidades pertencem tanto ao passado quanto ao futuro. Por mais que sejam marcadas por uma historicidade, elas são objeto de incessantes reinvestimentos, em outras palavras, longe de se constituírem tấo somente como restauração pretérita, as identidades demandam que nos posicionemos perante essas narrativas do passado.

A noção de "identidade", em Castiel Vitorino, só se pode deslindar crioulizada, pois nela se instaura a radical necessidade de uma "criaçáo" que nega e ignora os limites discursivos impostos ao corpo sexuado e generificado, no qual o cálculo reprodutivo se instrumentaliza a serviço da economia, da religiáo, da biologia, da medicina, para proscrever toda e qualquer dissonância ou dissidência que ameace a ilusória solidez binária do edifício logofonocêntrico ocidental.

O corpo "transmutado" que surge da poética de Castiel Vitorino é desde sempre o corpo da subversão paródica das noçóes assentadas atinentes ao sistema corpo-sexo-gênero. Corpo que demanda seu reconhecimento, em razão daquilo que Judith Butler denominará a "performatividade de gênero", assim descrito pelo filósofo Paul B. Preciado: 
Esses performativos de gênero são fragmentos de linguagem carregados historicamente do poder de investir um corpo como masculino ou feminino, bem como de sancionar os corpos que ameaçam a coerência do sistema sexo/gênero até o ponto de submetê-los a processos cirúrgicos de "cosmética sexual" (diminuição do tamanho do clitóris, aumento do tamanho do pênis, fabricação de seios de silicone, refeminização hormonal do rosto etc. (PRECIADO, 2017, p. 28-29).

Corpo do desregramento, a reclamar sua inscrição como singularidade poética. O corpo-obra de Castiel Vitorino aparenta ecoar as palavras de Virginie Despentes, no prefácio do livro Testo Junkie, de Paul B. Preciado: "Um ensaio corporal. Uma ficção na verdade. Se for preciso levar as coisas ao extremo, é uma ficção autopolítica ou uma autoteoria." (PRECIADO, 2018, p. 13). Esse corpo-obra, como ora o nomeamos, parece entregar-nos aquilo que Despentes enxerga no texto de Preciado: uma ficção teórica e política que surge a partir do corpo e que se autolegifera.

Nesse corpo que Castiel fabrica, os títulos das obras são instrutivos - Romaria dos testículos femininos (2019), Macete para crescer peito (2019), Sagrado feminino de merda (2019) -, o que nos conduz a outro texto de Preciado, no qual o autor descortina a sexuação e generificação dos corpos como materialização prostética e "genitalizada": "A identidade sexual não é a expressão instintiva da verdade pré-discursiva da carne, e sim um efeito de reinscrição das práticas de gênero no corpo.” (PRECIADO, 2017, p. 29). O gênero se faz e se desfaz incessantemente. Ele se dá em trânsito perpétuo. $\mathrm{O}$ corpo travesti subverte e recusa qualquer tentativa de instrumentalizaçáo e acomodação discursiva de sua genitalização.

Os saberes de uma tradição ancestral, a que Castiel nomeia "tecnologias bantu” (VITORINO, 2020, p. 234), são transmutados em suas performances, no intuito de fazer "surgir" essa Castiel que esse saber crioulizado é capaz de gerar. Essa ancestralidade, a perder-se na noite dos tempos ou na escuridão cruel e dolorosa do ventre do navio negreiro ou nas estratégias necropolíticas de extermínio das populaçóes ameríndias, é o que é preciso "recordar", por meio da invenção/fabulação artística que os "saberes" embutidos na práxis artística contemporânea é capaz de conceder ao sujeito que se (re)descobre: "Os mortos nos conclamam a lembrar. Alguns de nós não abandonaram esses ensinamentos. Ouvimos a voz de nosso passado africano insistindo para que nos lembremos que "um povo sem ancestrais é como uma árvore sem raízes." (HOOKS, 2019, p. 319). 
A performance Macete para crescer peito, de 2019, de 40min de duração, apresentada no Teatro Espanca, em Belo Horizonte, para o Festival de Arte Negra, é uma obra na qual se confundem mais explicitamente o teatro e a pintura, como se os leram aqui segundo Hubert Damisch, sobretudo pelo fato de que essa performance se dá em uma arena teatral no centro da qual se vê uma mesa a evocar, como se o lê aqui, uma natureza-morta.

Historicamente, a natureza-morta encerrava a alegoria da vanitas: a noção mesma de transitoriedade, de que os objetos expostos sobre a mesa que tanto podem servir à ostentação como ao memento mori (a lembrança da inevitabilidade da morte), vida e morte entrelaçam-se. É curioso notar como uma artista contemporânea como Sam Taylor-Johnson (1967), ao valer-se da possibilidade de dar a ver o movimento de dissolução dos objetos perecíveis a compor suas naturezas-mortas em vídeo, não se intimida diante da putrefaçáo e decomposição a que se encontra destinada a matéria viva. É nessa zona de indefinição, na qual a transmutação implica a passagem de um estado a outro, que parece repousar o interesse de Castiel Vitorino. Não lhe interessa a aparente solidez cromática embutida no azul e no vermelho, cores primárias, mas essa cor que nasce impura, ou, nos termos de Glissant, crioulizada.

O texto que acompanha os registros em vídeo e fotografia, no site de Castiel Vitorino, ecoa essa zona em que pairam Eros e Thanatos:

A dor da morte é azul e a vida parece vermelha. Eu sou uma trava negra mas quero ser roxa. Misturar viver e morrer que é a transmutação [...] E na umbanda, aprendi com caboclos e sereias sobre seus corpos híbridos de mar, terra e ar [...] Transmutar é isso: negociaçóes entre vida e morte. (VITORINO BRASILEIRO, 2019).

Que o roxo seja justamente a cor resultante da mistura do azul "vida" - e da morte - "vermelho" é o que poeticamente constitui "Castiel" como uma "figura” em trânsito e mutação. Os corpos híbridos, como os das sereias que povoam as mitologias caboclas, fascinam a artista, em seu trânsito de metamorfoses e mutaçóes que operam limítrofes como signos litorais um entre-lugar - espaço de radicalidade inventiva e poética. O amparo na dimensão mítica das narrativas de origem aparenta constituir-se como um repositório vocabular que se converte em material de citaçáo. E, uma vez citado, o material se reitera, a um só tempo reconhecível e outro (DIDIHUBERMAN, 2015). A arte contemporânea torna-se, por conseguinte, esse terreno fantasmal, espectral, em que a citação se desdobra sob os disfarces 
da alusão e da estilização. A citação, dentro dos domínios poéticos de Castiel Vitorino Brasileiro, é uma aliada de sua poiesis de transmutaçóes em permanente porvir.

\section{CONSIDERaÇóES Finais}

Diante do soterramento a que a interdição escritural da disciplina histórica condenou as narrativas dos corpos negros diaspóricos e dos corpos ameríndios - originários - exterminados, Castiel Vitorino Brasileiro encontra um desafio suplementar: apresentar a sua versão transmutada de um corpo cuja inscrição sexuada ou generificada à margem da matriz cisnormativa insiste em negar, apagar. O cálculo figurativo-representacional desse corpo que se encontra em permanente construção - in progress - forçosamente borra as fronteiras entre vida e arte e aponta para um interstício entre o representável e o irrepresentável. Ele é a um só tempo aparição e arena, na qual se encenam tensôes representacionais.

O sistema corpo-sexo-gênero confirma, como se lê em Judith Butler, a inexistência de uma substância que o pudesse legitimar como desde sempre "dado" pela crença anatômica que anda de máos dadas com o cálculo reprodutivo, em que o binarismo da anatomia se torna a fundação mais basilar de todo o edifício do logofonocentrismo no Ocidente.

Um corpo cuja identidade se (des)fia diante de nossos olhos e cujo cálculo final nos escapa, uma vez que essa figuração se dá como passagem e como limite (DERRIDA, 1991). Uma espécie de dedo imaginário e metafórico aponta para o "fora do quadro", tido aqui como aquilo que o enquadramento representacional contém, dentro dos domínios encerrados pela moldura, o parergon de que nos fala Derrida (1978, p. 44-168), torna-se um elemento constitutivo da própria obra, como essa espécie de estrutura que autoriza que se possa ver aquilo que seus limites físicos emolduram.

Proporíamos, assim, que se possa, a partir das ressonâncias de sobrevivências - Nachleben (WARBURG, 2014, p. 10) - pictóricas e teatrais, ${ }^{4}$ nessa obra de Castiel Vitorino, pensar nessa zona intersticial, no litoral em que a transmutação de que tanto se ocupa em sua poiesis como um campo de invenção no qual os motivos pretéritos de sua ancestralidade e religiosidade

\footnotetext{
${ }^{4}$ Para uma outra e específica leitura do que ressonâncias de ordem performativa atinentes ao corpo transgênere, ver: Leal (2018).
} 
afroindígenas, assim como as mutaçóes metamorfoseadas das sobrevivências waburgianas, possam fornecer o repertório sígnico em torno do qual a práxis crioulizada de Castiel Vitorino possa desdobrar-se em uma espécie de (re) escritura de um sujeito cuja existência demanda sua invenção para fora daquilo que o edifício representacional, discursivo e imagético ocidental lhe reservou. O "fora-do-quadro" ou o "além-moldura", ao mesmo tempo que se oculta do campo de visibilidade, sugere que há algo que se insinua num para além do que já se encontra dado a ver.

Essa fabulação inventiva se dá forçosamente a partir dos rastros e resíduos a que nos remete Édouard Glissant. Ela se vale desses motivos de um passado a um só tempo vivido e imaginado. Diante do apagamento a que se condenou a negritude, as dissonâncias do sistema corpo-sexo- gênero, em relação à hegemonia suprematista branca e à matriz cisnormativa, a subversão, a qual Butler interpretará como paródia (2010), precisa aqui ser compreendida igualmente em suas ressonâncias trágicas e gozosas, como sugerimos em nosso texto, ao enxergar na figura da artista Castiel Vitorino Brasileiro uma Antígona afroindígena brasileira. Para a história daquilo que seu corpo encerra como urgência identitária, Castiel existe como uma invenção poética que se dá $a$ posteriori, nesse terreno em que vida e morte se cruzam incessantes.

Em seu mergulho na escuridão desse oceano que é o Atlântico negro e no interior desta terra em que povos pré-cabralinos se dizimaram, Castiel afirma sua "macumbaria", a um só tempo ancestral e artística, em que a criatura Castiel se invoca a partir de uma ritualística de apariçóes que se recompóem, em função de uma arqueologia dos affetti e dos indícios e pistas que se depositaram nos ritos de uma religiosidade que se torna, ela também, objeto dos investimentos poéticos da artista.

No rito que é sua poiesis, Castiel faz com que a relação entre sujeito e objeto se subverta, com que se fundam um no outro, a ponto de que as determinaçôes desejantes daquilo que se anuncia na "aparição" possam se assenhorar da cena que se desenrola diante de nossos olhos. Algo ali se dá à revelia da consciência, ainda que a encenação dependa da fisicalidade ritualística que se poderia pensar, à maneira de uma poiesis, de uma técnica invocatória, como que a evocar aquilo que Jacques Lacan ressalta do sonho: “[...] no estado de vigília, há elisão do olhar, elisão do fato de que não só isso olha, mas que isso mostra. No campo do sonho, ao contrário, o que caracteriza as imagens é que isso mostra." (LACAN, 1996, p. 76). 
Uma vez que Castiel Vitorino se expressa poeticamente, por meio de performances, o recurso ao aparato de sustentação representacional embutido no modelo pictórico pode, à primeira vista, padecer de insuficiência ou inadequação, uma vez que estamos diante de uma poética na qual o corpo mesmo da artista é o agente, a superfície e o locus do acontecimento poético. Todavia, o corpo de Castiel continua a oferecer-se ao olhar, que precisa decodificá-lo e, por mais que sua inscrição resista a uma definição categórica, o movimento em permanente trânsito e a translação figural de Castiel convertem-se no constitutivo de um mundo habituado à espetacularização dos corpos. Que seu corpo dissonante, no que tange à hegemonia midiática, possa ele também se oferecer, mesmo que em sua condição de enigma, não o exclui da lógica representacional amparada pelo modelo pictórico que ora se desconstrói. Esse corpo encerra não apenas um complexo embate representacional: ele aponta $\mathrm{e}$ mostra um para-além de toda a representação naturalizada.

VIEIRA, M. A. Afro-Brazilian travesti voodoo in Castiel Vitorino Brasileiro or the implosion of the theatre of representation: body, gender, blackness. Trans/Form/Açáo, Marília, v. 45, p. 265-290, 2022. Edição Especial.

\begin{abstract}
Our interest herein resides in how the poetical, black and travesti body of the artist Castiel Vitorino Brasileiro opposes and confronts the hegemonic Art History and its System, while contributing to a revision of its discursive practices of inclusion and exclusion through its poiesis, its poetical fabrication in which the artist's afro-ameridian ancestry is both visited and reinvented. The apparition and vision of Castiel's black, dissident body suggests, in our reading, a destabilization of what Hubert Damisch calls "the theatre of representation". Theoretically, this text resorts to a field characterized by interdisciplinarity with a view to attempting to contemplate the complexity of its objet: gender studies, queer theory, philosophy, Lacanian theory, art history and theory, which would qualify it as an exercise in Cultural Analysis, as Dutch theorist Mieke Bal would have it.
\end{abstract}

Keywords: Gender. Body. Blackness. Cultural Analysis. Art Theory and History.

\title{
REFERÊNCIAS
}

ARASSE, Daniel. A carne, a graça, o sublime. In: VIGARELLO, Georges (dir.) História do Corpo 1- Da Renascença às Luzes. Tradução de Lucia M. E. Orth. Revisão da tradução de Ephraim Ferreira Alves. Petrópolis: Vozes, 2005. p. 535-620. 
BAL, Mieke (ed.). Introduction. In: The practice of cultural analysis - exposing interdisciplinary interpretation. Stanford: Stanford University Press, 1999. p. 1-14.

BAXANDALL, Michael. Giotto e os oradores - as observaçôes dos humanistas italianos sobre pintura e a descoberta da composição pictórica (1350-1450). Tradução de Fábio Larsson. São Paulo: EDUSP, 2018.

BULHÓES, Maria Amélia (org.). As novas regras do jogo: o sistema de arte no Brasil. Porto Alegre: Zouk, 2014.

BRASILEIRO, Castiel Vitorino. Macete para crescer peito. 2019. Disponível em: https://castielvitorinobrasileiro.com/perfor_macete. Acesso em: 16 ago. 2020.

BRASILEIRO, Castiel Vitorino. Entrevista concedida a Rizzia Rocha e Luís Thiago Dantas. ArteFilosofia - Revista do Programa de Pós-Graduação em Filosofia da UFOP, Ouro Preto, v. 15, n. 28, p. 233-238, abr. 2020.

BUTLER, Judith. Problemas de gênero - feminismo e subversão de identidade. Tradução de Renato Aguiar. Rio de Janeiro: Civilização Brasileira, 2010.

BUTLER, Judith. O clamor de Antígona - parentesco entre a vida e morte. Tradução de André Cechinel. Florianópolis: UFSC, 2014.

BUTLER, Judith. Corpos que importam - os limites discursivos do sexo. Tradução de Veronica Daminelli e Daniel Yago Françoli. São Paulo: N-1 Ediçôes \& Crocodilo, 2019.

CERTEAU, Michel de. História e psicanálise- entre ciência e ficção, tradução de Guilherme João de Freitas Teixeira. 2 ed. Belo Horizonte: Autêntica, 1987/2011.

DAMISCH, Hubert. Théorie du nuage - pour une histoire de la peinture. Paris: Seuil, 1972.

DERRIDA, Jacques. La vérité en peinture. Paris: Flammarion, 1978.

DERRIDA, Jacques. Margens da Filosofia. Tradução de Joaquim Torres Costa \& António M. Magalhães. São Paulo: Papirus, 1991.

DERRIDA, Jacques. A escritura e a diferença. Tradução de Maria Beatriz Marques Nizza da Silva, 2. ed. São Paulo: Perspectiva, 1995.

DIDI-HUBERMAN, Georges. Passés Cités par JLG - L’oeil de L'Histoire, 5. Paris: Minuit, 2015.

EINSTEIN, Carl. Negerplastik. Tradução de Fernando Scheibe e Inês de Araújo. Florianópolis: UFSC, 2011.

FOSTER, Hal et al. "1992” In: Art since 1900 - modernism, antimodernism, postmodernism. Londres: Thames \& Hudson, 2011. p. 668-673.

GLISSANT, Édouard. Introduçáo a uma poética da diversidade. Tradução de Eunice do Carmo Albergaria Rocha. Juiz de Fora: UFJF, 2013. 
HALL, Stuart. Da diáspora: identidades e mediaçóes. Tradução de Adelaine de la Guardia Resende, Ana Carolina Escosteguy, Claudia Alvares, Francisco Rudiger e Sayonara Amaral. Belo Horizonte: UFMG, 2013.

HARNONCOURT, Nikolaus. Baroque music today, music as speech - ways to a new understanding of music. Londres: Amadeus, 1988.

HARTOG, François. Evidência da história - o que os historiadores veem. Tradução de Guilherme João de Freitas Teixeira, com a colaboração de Jaime A. Clasen. Belo Horizonte: Autêntica, 2011.

HOOKS, Bell. Olhares negros: raça e representação. Tradução de Stephanie Borges. São Paulo: Elefante, 2019.

LACAN, Jacques. Le séminaire livre XX: encore. Paris: Seuil, 1975.

LACAN, Jacques. O Seminário Livro XI - os quatro conceitos fundamentais da psicanálise. Tradução de M. D. Magno. Rio de Janeiro: Zahar, 1996.

LEAL, Dodi. Performatividade transgênera: equações poéticas de reconhecimento recíproco na recepção teatral. 2018. 534p. Tese (Doutorado em Psicologia Social) Instituto de Psicologia, Universidade de São Paulo, São Paulo, 2018.

LIMA, Luiz Costa. História, ficçáo, literatura. São Paulo: Companhia das Letras, 2006.

MANDRESSI, Rafael.Dissecações e Anatomia. In: VIGARELLO, Georges (dir.)

História do Corpo 1- Da Renascença às Luzes. Tradução de Lucia M. E. Orth. Revisão da tradução de Ephraim Ferreira Alves. Petrópolis: Vozes, 2005. p. 411-440.

MARIN, Louis. Sublime Poussin. Tradução de Mary Amazonas Leite de Barros. São Paulo: EDUSP, 2001.

MBEMBE, Achille. Crítica da razão negra. Tradução de Sebastião Nascimento. São Paulo: N-1 Ediçóes, 2018a.

MBEMBE, Achille. Necropolítica. Tradução de Renata Santini. São Paulo: N-1 Edições, 2018 b.

MOMBAÇA, Jota. Náo váo nos matar agora. Rio de Janeiro: Cobogó, 2021.

MUDIMBE, V. Y. The invention of Africa - gnosis, philosophy and the order of knowledge. EUA: Indiana University Press, 1988.

NASCIMENTO, Abdias. O genocídio do negro brasileiro - processo de um racismo mascarado. São Paulo: Perspectiva, 2016.

OGUIBE, Olu. In the Heart of Darkness. Third Text, v. 7, n. 23, p. 3-8, mar. 1993.

PETRY, Michael. Revisiting the Still-Life. In: Nature-Morte: contemporary artists reinvigorate the still-life tradition. Londres: Thames \& Hudson, 2016. p. 6-18. 
POLLOCK, Griselda.Feminist interventions in the Histories of Art. In: Vision and Difference: Femininity, Feminism and the Histories of Art. Londres: Routledge, 2003. p. 1-17.

PRECIADO, Paul B. Manifesto contrassexual - práticas subversivas da identidade sexual. Tradução de Maria Paula Gurgel Ribeiro, com a colaboração de Verônica Daminelli Fernandes. São Paulo: N-1 Ediçóes, 2017.

PRECIADO, Paul B. Testo Junkie - sexo, drogas e biopolítica na era farmacopornográfica. Tradução de Maria Paula Gurgel Ribeiro, com a colaboraçáo de Verônica Daminelli Fernandes. São Paulo: N-1 Ediçôes, 2018.

PRECIADO, Paul B. Um apartamento em Urano - crônicas da travessia. Tradução de Eliana Aguiar. Rio de Janeiro: Zahar, 2020.

RICOEUR, Paul. A memória, a história, o esquecimento. Tradução de Alain François. Campinas: UNICAMP, 2007.

SPIVAK, Gayatri C. Pode o subalterno falar? Tradução de Sandra Regina Goulart Almeida, Marcos Pereira Feitosa e André Pereira Feitosa. Belo Horizonte: UFMG, 2010.

WARBURG, Aby. Histórias de fantasma para gente grande - escritos, esboços e conferências. Organização de Leopoldo Waizbort. Tradução de Lenin Bicudo Bárbara. São Paulo: Companhia das Letras, 2014.

WHITE, Hayden. Trópicos do discurso - ensaios sobre a crítica da cultura. Tradução de Alípio Correia de Franca Neto. 2. ed. 1. reimpr. São Paulo: EDUSP, 2014.

Recebido: 01/6/2020

Aceito: $17 / 8 / 2020$ 
VIEIRA, M. A. 